\title{
G060064
}

\section{円筒容器内の凍結漕縮に関する実験的研究 （溶液の凍結に及ぼす温度勾配の影響について）}

\author{
○学 飯塚 誠也（新潟大）＼cjkstart正 松原 幸治（新潟大） \\ 正 櫻井 篤 (新潟大) 正 松平 雄策（新潟大） \\ Seiya Iizuka, Koji Matsubara ,Atsushi Sakurai and Yusaku Matsudaira \\ Niigata University, Ikarashi2-nocho 8050, Niigata 950-2181
}

An experimental study was performed for freeze-concentration of $1 \%$ water-solution of sodium chloride in a cylindrical container, where a heat transfer pipe was set vertically. Experimental results denoted that temperature gradient in the ice promote solute rejection. When the ice is given a temperature gradient for long time , solute is eliminated little by little from the ice. By varying the temperature of the inner wall, the difference of concentration rate, distribution coefficient and concentration of ice was measured.

Key Words: Freeze-concentration, cylindrical container, sodium chloride, heating, temperature gradient

\section{1. 䊩}

凍結濃縮とは，溶液が凝固する際に溶質を排除する効果を利用した溶液の濃縮法 ${ }^{(1)}$ であり，食品や医薬品など の濃縮や各種の製造プロセスへの応用が検討されている. 本研究では, 円筒型容器を用い, 容器の内壁温度を変 化させ温度勾配を水内に発生させる実験を行ったので，その効果について報告する。

\section{2. 实臨手法}

実験装置およびテストセクションの概略図をそれぞれ図 1，図 2 に示す．チラーを用いてタンク内のブライン を冷却し，伝熱管（直径 $16 \mathrm{~mm}$ ）内に流すことで伝熱管を冷却する. 伝熱管はアクリル樹脂製の円筒型容器（内 側の高さ $155 \mathrm{~mm}$, 内径 $57 \mathrm{~mm}$ ）に入れた溶液中に挿入し，伝熱管表面におういて溶液を凍結させ，未凍結部の濃縮 を行う. 濃縮対象となる水溶液の溶質には塩化ナトリウムを用いた。初期濃度を $1.0 \%$ と, 容器の外周部にラバ 一ヒーターを巻きつける事により外側からは加熱, 内側からは冷却をして容器内, および氷内に温度勾配を発生 させ実験を行った，実験条件は表 1 に示す.

Table 1 Experimental condition

\begin{tabular}{|l|l|c|}
\hline Solvent & \multicolumn{2}{|c|}{$\mathrm{NaCl}$} \\
\hline Solution mass & \multicolumn{2}{|c|}{$330 \mathrm{~g}$} \\
\hline $\begin{array}{l}\text { Initial } \\
\text { concentration }\end{array}$ & \multicolumn{2}{|c|}{$1.0 \%$} \\
\hline $\begin{array}{l}\text { Heat transfer } \\
\text { surface } \\
\text { temperature }\end{array}$ & \multicolumn{2}{|c|}{$-4^{\circ} \mathrm{C}$} \\
\hline Condition & insulation & heating \\
\hline $\begin{array}{l}\text { Temperature of } \\
\text { inner wall }\end{array}$ & $-3^{\circ} \mathrm{C}$ & $0,5^{\circ} \mathrm{C}$ \\
\hline
\end{tabular}

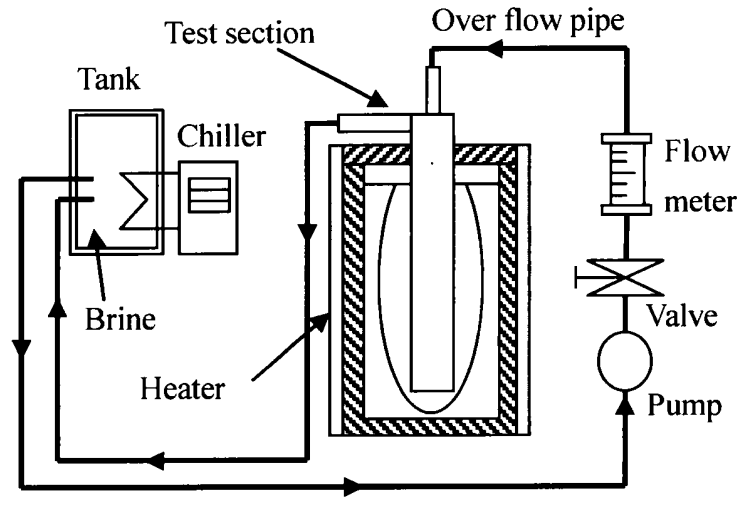

Fig. 1 Experimental apparatus

${ }^{* 1}$ 学生員, 飯塚誠也 新潟大学大学院 自然科学研究科（广950-2181 新潟県新潟市西区五十嵐 20 0町 8050)

2 正員, 松原幸治 櫻井篤 松平雄策 新潟大学大学院 自然科学研究科

E-mail: seiya.nabi@gmail.com

[No.12-1] 日本機械学会 2012 年度年次大会講演論文集 [2012.9.9-12, 金沢] 


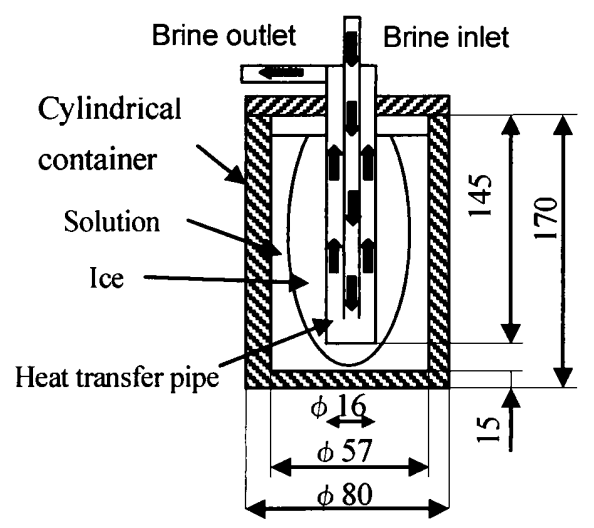

Fig. 2 Test section

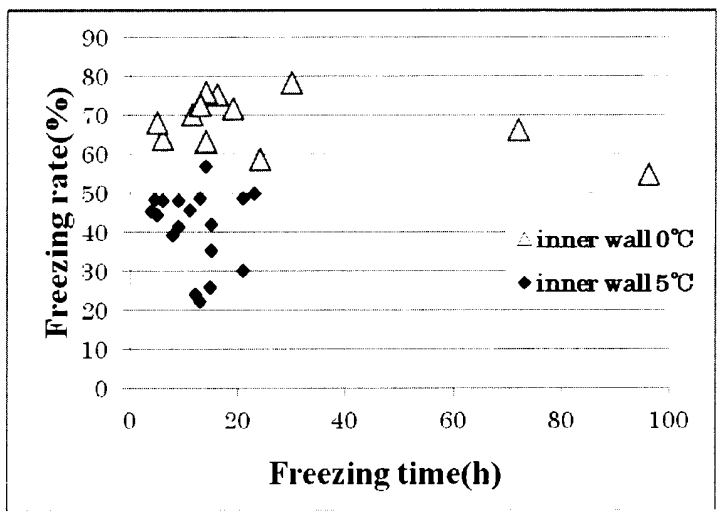

Fig. 3 The relationship between freezing rate and freezing time

\section{3. 实験結果}

\section{1 温度勾配による溶質排除への影警}

図 3 に凍結率と凍結時間のグラフを示す．凍結率自体にバラつきはあるものの凍結の開始後，約 3 時間で水は 完全に成長している状態になっているといえる.

図 4 には水の見かけの濃度と凍結時間のグラフを示す．グラフから明らかに凍結時間が長くなるにつれて氷の 見かけの濃度が低下していることが分かる. 凍結率には凍結時間 3 時間の時点から変化がないことから一度完全 に成長した氷からも温度勾配により溶質が排除されている事が示唆された. また壁面温度は $0^{\circ} \mathrm{C}$ ○時より $5^{\circ} \mathrm{C}$ 時 のほうが溶質の排除が素早く起こる事が分かる．理由としては温度勾配の大きさと凍結率の差によるものだと考 えられる.

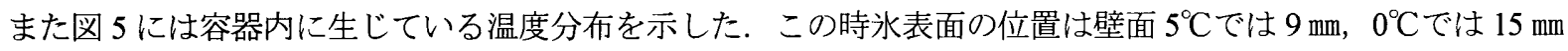
の位置に達しており, 水内に温度勾配が生じている事が確認できる.

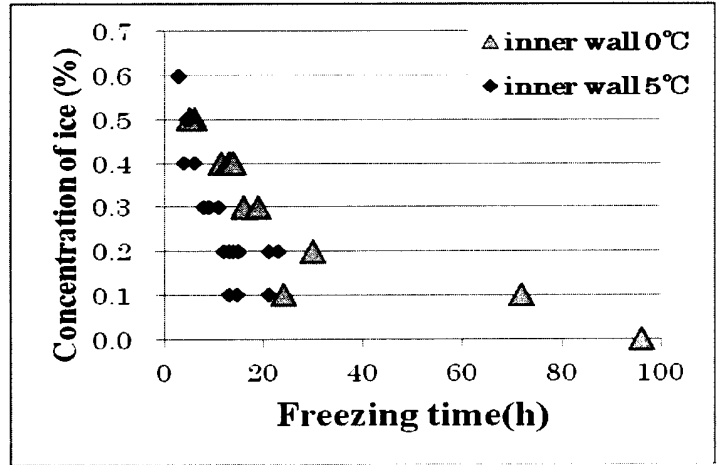

Fig. 4 The relationship between concentration of ice and freezing time

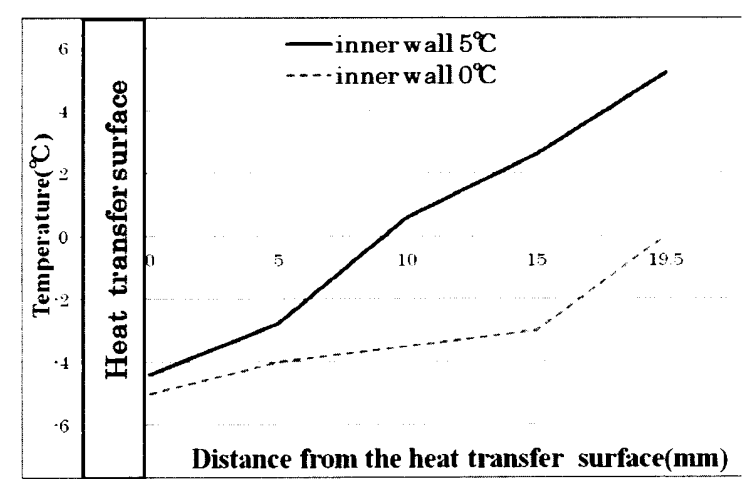

Fig. 5 Temperature distribution in the container

\section{2 内壁面温度の違いによる浱縮倍率の違い}

図 6 に濃縮倍率と凍結時間の関係のグラフを示した。こちらのグラフから図 3 の凍結率に関するグラフと類似 した結果が得られた．凍結率が最大の $78 \%$ に達した凍結時間 $30 \mathrm{~h}$ の実験で最大の濃縮倍率 4.1 倍となった.

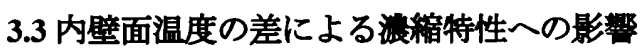

それぞれの実験值から濃縮特性を比較するために，見かけの分配係数を用いる．この值は，氷表面近傍に存在 する溶質のうち氷内部の間隙に取り込まれる溶質の割合である. 見かけの分配係数 $\mathrm{k} か ゙$ 凍結率に関わらず一定で あると仮定すると，次式が導出される. 


$$
\frac{\varepsilon_{L}}{\varepsilon_{L 0}}=\left(1-\frac{G_{S}}{G_{L 0}}\right)^{k-1}
$$

ここで， $\varepsilon_{L}$ は溶液濃度， $\varepsilon_{I O}$ は溶液初期濃度， $G_{S}$ は凍結部質量， $G_{I .0}$ は溶液初期質量である.

図 7 に凍結時間と見かけの分配係数 $\mathrm{k}$ のグラフを示寸. グラフより図 4 の水の見かけの濃度のグラフ同様に凍 結時間が長くなるほど良好な値になる結果となった。しかし水の見かけの濃度と違い，見かけの分配係数は内壁 が $5^{\circ} \mathrm{C}$ より $0^{\circ} \mathrm{C}$ 結果の方がわずかに良好な值を示すことが確認された. よって温度勾配を与える方法では, 大量 の水を生成した方が良好な濃縮が可能となることが示唆された。

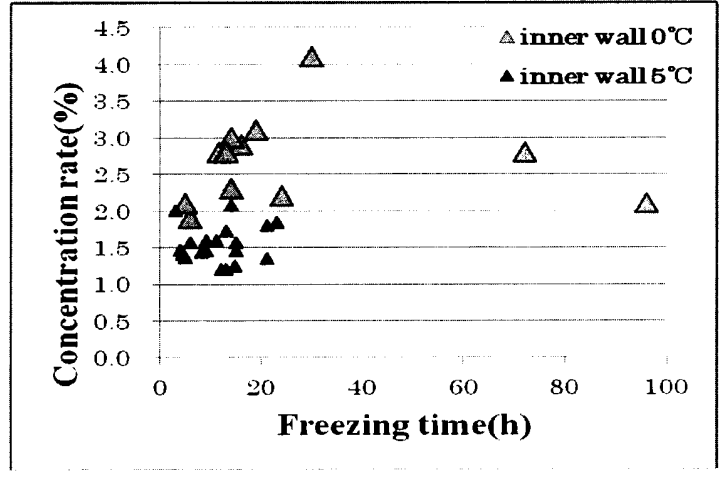

Fig. 6 The relationship between concentration rate and freezing time

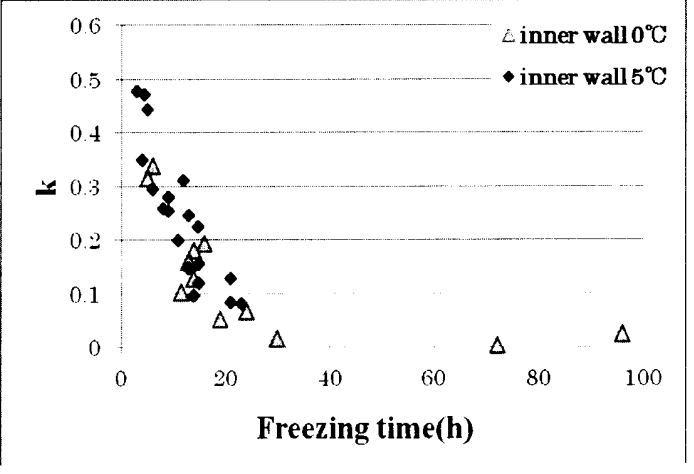

Fig. 7 The relationship between distribution coefficient and freezing time

\section{4 温度勾配による溶質排除のプロセス}

水内の高濃度溶液が排除される事例として, 海水の研究例(2)があり同様の現象が今回の実験でも起こっている と考えられる。水内に取り込まれている溶質は高濃度溶液として液体状態で存在している. この時, 凝固点効果 の影響で，ある温度で涷結しない限界の濃度を保っている．ここに温度勾配を与えると温度の高い側では高濃度 溶液の濃度を下げる為周りの水を溶かし，逆に低温側では氷を生成し濃度を高める動きをする．この過程を繰り 返し氷内の高濃度溶液は温度の高い側一排出されると考えられる。

\section{4. 結量}

円筒容器を用いて塩化ナトリウム水溶液に温度勾配を与えて凍結濃縮実験を行った結果, 以下のことが明らか になった.

(1) 円筒容器内の水に水平方向の温度勾配を与えながら椧却を続ける事により氷内の溶質が徐々に排除されるこ とが確認された.

(2) 凍結率, 濃縮倍率, 見かけの分配係数の関係より凍結量が多いほど良好な濃縮が可能になることが示唆され た.

（3）一度生成された氷から温度勾配により溶質が排除されるプロセスを確認した。

\section{参考文献}

（1）井口・黒田，流下液膜式凍結濃縮装置，冷凍，78(-904), 119-124(2003)

(2) 田畑・小野, 海水の構造 低温科學(1957) 